Hydrology and Earth System Sciences, 8(3), 578-588 (2004) C EGU

\title{
The effects of riparian forestry on invertebrate drift and brown trout in upland streams of contrasting acidity
}

\author{
S.J. Ormerod, M.E. Jones, M.C. Jones and D.R. Phillips \\ Catchment Research Group, Cardiff School of Biosciences, Cardiff University, PO Box 915, Cardiff CF10 3TL, UK
}

E-mail for corresponding author: ormerod@cardiff.ac.uk

\begin{abstract}
Variations in macroinvertebrate drift and benthic invertebrate abundance were assessed in 30 upland Welsh streams of varying acidity ( $\mathrm{pH}<$ 5.7 or $\mathrm{pH} .>6.0$ ) and riparian land-use (conifer, moorland or native broadleaf). The consequences for the diet and condition of wild brown trout Salmo trutta were also assessed. As expected from previous studies, there were significant reductions in benthic invertebrate abundance, aquatic drift density (by $>60 \%$ ), aquatic drift biomass (by $>35 \%$ ), total drift density (by $>35 \%$ ) and total drift biomass (by $>20 \%$ ) at acid sites by comparison with circumneutral sites due largely to the scarcity of mayflies. Absolute drift from terrestrial sources was unrelated to stream $\mathrm{pH}$ but formed a significantly greater proportion of total drift at acid sites (30-65\% of density) than at circumneutral sites $(20-40 \%)$ as aquatic contributions declined. Most of this apparent land use effect reflected significantly increased terrestrial drift under broadleaves. There was no significant reduction in terrestrial or aquatic drift at conifer forest sites per se after accounting for low $\mathrm{pH}$. Trout diet varied substantially between locations partly reflecting variations in drift: significantly fewer mayflies and stoneflies were eaten at acid sites, and significantly more terrestrial prey were eaten under broadleaves. However, acidity did not reduce trout condition or gut-fullness. Unexpectedly, trout condition was significantly enhanced at conifer sites, irrespective of their $\mathrm{pH}$. Hence, acidity has greater effects on the benthic abundance and drift density of invertebrates in upland streams than does riparian land use. However, trout forage flexibly enough to offset any possible food deficit, for example by switching to chironomids and terrestrial invertebrates. Enhanced terrestrial contributions to invertebrate drift from riparian broadleaf trees may be important in supplementing foraging opportunities for trout where aquatic prey are scarce. These data illustrate the value of native tree species in riparian locations in upland Britain and the energy subsidy they provide might well be disproportionately important for otherwise impoverished acid streams.
\end{abstract}

Keywords: brown trout, land-use, acidification, drift, forestry, streams

\section{Introduction}

Although of long-standing interest (Mason and MacDonald, 1982), the reciprocal flow of energy across the riparianstream ecotone has recently been the subject of renewed focus (Nakano and Murakami, 2001). This follows recent recognition that terrestrial invertebrates falling into streams from riparian vegetation provide not only an important energy subsidy to fishes and other vertebrates, but can also lead to secondary effects that permeate upwards or downwards through food webs (Nakao et al., 1999; Kawaguchi et al., 2003; Sabo and Power, 2002). Alterations to the species mix or cover of riparian vegetation might therefore have pronounced energetic effects on whole stream ecosystems (Allan et al., 2003; England and Rosemond, 2004).
Production forestry adjacent to streams represents a potentially profound modification to riparian energy flow. In the most extreme cases, exotic tree species in plantations alter patterns of shading and stream inputs of litter, woody debris and terrestrial invertebrates by comparison with native trees or grazing land (Ormerod and Tyler, 1991; Pretty and Dobson, 2004; Collen et al., 2004). In Britain these effects are compounded since many forests are located along rivers that are already impoverished biologically due to surface water acidification (Ormerod et al., 1989). So far, however, studies of the interacting effects of land use and low $\mathrm{pH}$ on terrestrial invertebrate subsidies to British streams have been few (Ormerod and Tyler, 1991; Bridcut, 2000). This is a substantial gap in understanding that could 
otherwise benefit the management of forests in riparian zones (Broadmeadow and Nisbet, 2004).

Brown trout (Salmo trutta L.) are among the top predators most at risk from effects due to acidification and altered prey availability. Although severe acidification affects brown trout by direct toxicity (Morris et al., 1989), interactions with altered food abundance are possible. In streams, their diet is dominated by drifting macroinvertebrates (Bachman, 1984), whose density and composition are likely to reflect either $\mathrm{pH}$ or riparian character (Harriman and Morrison, 1982; Ormerod et al., 1987, 1993; Ormerod and Wade, 1990; Ormerod and Tyler, 1991). Nevertheless, Turnpenny et al. (1987) suggested that the effects of acidification on the stream benthos might not limit trout because terrestrial contributions to drifting prey would offset any resulting food scarcity. Factors that reduced terrestrial prey inputs to acid streams - for example streamside conifers in temperate areas more naturally occupied by broadleaves - could, thus, be important. Moreover, since land-use will influence terrestrial invertebrate inputs to rivers independently of acidification (Sedell et al, 1975; Ormerod and Tyler, 1991), there are good reasons to assess the consequences for trout even at high $\mathrm{pH}$, or where streams recovering from past acidification might now be regaining salmonid populations.

Here, the effects of acidity and three riparian land-uses (conifer forest, broadleaf woodland, moorland) on macroinvertebrate drift and benthic abundance in upland Wales were examined, simultaneously, with brown trout diet and condition. On the basis of available literature, it was predicted that :

(i) The density of aquatic drift and abundance of benthic invertebrates would be reduced at acid sites, with terrestrial drift unaffected (following Ormerod and Wade, 1990 and references above);

(ii) The density of terrestrial drift would be greatest at broadleaf and least in conifer sites (following Ormerod and Tyler, 1991);

(iii) The diet and condition of brown trout would follow predictions i) to ii), with negative effects most likely at acid sites in conifers.

\section{Study area and methods}

All predictions were tested simultaneously on 30 widely scattered Welsh streams, arranged in a hierarchical ANOVA (analysis of variance) design (Table 1). From sites that formed a previous larger survey (Ormerod et al., 1989), five replicate streams were selected in the three land-uses in both acid $(\mathrm{pH}<5.7)$ and circumneutral categories $(\mathrm{pH}>6.0)$. Streams were categorised in this way because major changes occur in the stream benthos around $\mathrm{pH}$ 5.7-6.0, which marks the $\mathrm{pH}$ range over which streams become increasingly subject to highly acid episodes (Weatherley and Ormerod, 1991); other measures of acid-base status were correlated with $\mathrm{pH}$, so that increased aluminium from $40-70 \mu \mathrm{g}^{-1}$ to $>$ $100 \mu \mathrm{g} \mathrm{l}^{-1}$, and decreased total hardness from $>15 \mathrm{mg} \mathrm{CaCO}_{3}$ $\mathrm{l}^{-1}$ to $<12 \mathrm{mg}^{-1}$ also occurred around this division (S.J. Ormerod et al. unpubl. data).

'Moorland' streams flowed through grasslands dominated by Molinia caerulea (L.), Nardus stricta L., Deschampsia spp., Holcus spp., Festuca spp., Agrostis spp. and Festuca spp. 'Broadleaf' streams were, inevitably, often fringed by trees rather than the whole catchment being tree-covered, and species included Alnus glutinosa (L.), Betula pendula Roth., Corylus avellana L., Quercus petraea (Mattuska), Cretaeugus mongyna Jacq, Sorbus aucuparia L. and Salix spp. The conifer areas included mostly mature ( $>25 \mathrm{yr}$ ) Picea sitchensis Carriere, occasionally with Picea abies (L.) or Pinus spp.; trees never overhung the stream, consistent with current forest management practice. Sites ranged from 80 to $440 \mathrm{~m}$ a.s.1, 1-6 $\mathrm{m}$ in width, and $0.07-0.18 \mathrm{~m}$ in depth at the time of sampling. Neither width nor depth varied between site groups. Although altitude was unrelated to $\mathrm{pH}$, broadleaf sites (mean $187 \mathrm{~m} \pm 74 \mathrm{SD}$ ) occurred at significantly lower altitudes than conifers (304 $\mathrm{m} \pm 76 \mathrm{SD}$ ) or moorlands (314 m $\pm 66 \mathrm{SD}$; ANOVA $\mathrm{F}_{2,27}=9.5$, $P<0.001$ ), indicative of the only locations where woodlands still remain in upland Wales.

The work was carried out between late July and early September, when significant effects of land-use on drift were most likely to show because tree canopies are well developed, and the input of terrestrial insects to streams is greatest (e.g. Ormerod and Tyler, 1991). Trout also feed actively over the summer, and both the daily (see below) and seasonal pattern of fish sampling would be most conducive to detecting terrestrial contributions to their diet (e.g. Elliott, 1970; Kelly-Quinn and Bracken, 1990; KellyQuinn, 1991).

\section{MACROINVERTEBRATE BENTHOS AND DRIFT}

Drift was assessed for consecutive four-hour periods over $24 \mathrm{~h}$ at each site using rectangular drift nets (length $1 \mathrm{~m}$, mouth $0.1 \mathrm{~m}^{2}$, mesh size $400 \mathrm{~m}$ ). These were secured in position by metal stakes at approximately $1-2 \mathrm{~cm}$ above the substratum, with the top of the frame above the stream surface to ensure the collection of floating terrestrial invertebrates. Drift density was quantified using stream 
Table 1. Sites used in this study, showing their riparian land use and mean $\mathrm{pH}$, based on monthly values between October and May.

\begin{tabular}{llllll}
\hline & AcID SITES & & \multicolumn{2}{c}{ CIRCUM-NEUTRAL SITES } \\
Site Grid & $\begin{array}{l}\text { Riparian } \\
\text { Reference }\end{array}$ & $\begin{array}{l}\text { Mean } \\
\text { land-use }\end{array}$ & $\begin{array}{l}\text { Site Gride } \\
\text { Reference }\end{array}$ & $\begin{array}{l}\text { Riparian } \\
\text { land-use }\end{array}$ & $\begin{array}{l}\text { Mean } \\
\text { pH value }\end{array}$ \\
\hline SH 774297 & Conifer & 5.4 & SH 749323 & Conifer & 6.2 \\
SH 683209 & Conifer & 5.7 & SO 267252 & Conifer & 7.2 \\
SN 841783 & Conifer & 5.6 & SO 048164 & Conifer & 6.1 \\
SN 839784 & Conifer & 5.6 & SO 061171 & Conifer & 7.0 \\
SN 848823 & Conifer & 5.6 & SO 238237 & Conifer & 7.1 \\
SH 576509 & Moorland & 5.3 & SH 755335 & Moorland & 6.1 \\
SH 779446 & Moorland & 5.1 & SN 994164 & Moorland & 6.7 \\
SN890722 & Moorland & 5.4 & SN 681545 & Moorland & 6.4 \\
SN 889723 & Moorland & 5.4 & SN 644516 & Moorland & 6.2 \\
SN 767869 & Moorland & 5.5 & SN 676089 & Moorland & 6.7 \\
SH 573500 & Broadleaf & 5.2 & SH 817229 & Broadleaf & 6.4 \\
SS 843903 & Broadleaf & 5.2 & SN 925207 & Broadleaf & 7.0 \\
SN 888799 & Broadleaf & 5.4 & SN 791129 & Broadleaf & 6.1 \\
SN 976777 & Broadleaf & 5.6 & SN 792128 & Broadleaf & 6.7 \\
SN 679405 & Broadleaf & 5.7 & SH 768289 & Broadleaf & 6.5 \\
\hline
\end{tabular}

discharge and the volume of water filtered per unit time (Allan and Russek, 1985).

Invertebrates were preserved on-site in 70\% alcohol. Aquatic taxa were subsequently identified to family, and terrestrial taxa to order. The total wet weight of invertebrate drift per cubic metre was calculated from weights of bulk samples. Benthic collections were made at each site following the assessment of drift by one semi-quantitative kick-sample of two-minutes duration (frame $230 \times 255 \mathrm{~mm}$; mesh size $355 \mathrm{~m}$ ). Like drift samples, they were identified to family in the laboratory and the bulk wet weight of each was recorded.

\section{TROUT CONDITION AND DIET}

At each site, brown trout were caught (under licence) using pulsed D.C. electrofishing equipment (Bohlin et al., 1989), anaesthetised using benzocaine at $25 \mathrm{ppm}$, weighed $(\mathrm{g})$ and fork length measured (mm). Trout condition was assessed on the entire catch using Fulton's Condition factor (see Turnpenny et al., 1987):

$$
\mathrm{K}=105 \times \text { fish weight }(\mathrm{g}) / \text { fish length }^{3}(\mathrm{~mm})
$$

Diet was assessed immediately after the measurement of drift at either twelve midday or four in the afternoon; this contemporaneous measurement was considered important because gut retention time in brown trout is less than four hours (Elliott, 1970). At most sites, a maximum of fifteen trout representing the site-specific range of age-classes was selected for analysis. At six sites where fish were scarce, only 7-9 were caught, but these smaller samples were still considered representative of the character of the site .

Stomach contents were removed using a non-destructive flushing method (Foster, 1977) which removed over 95\% of prey eaten (Light et al., 1983); all fish survived the procedure. A $60 \mathrm{ml}$ syringe and tubing of two different diameters were used in the process, the larger tube (internal diameter $3.5 \mathrm{~mm}$, external diameter $4.5 \mathrm{~mm}$ ) being used on fish larger than $125 \mathrm{~mm}$, and the smaller (internal diameter $1.5 \mathrm{~mm}$, external diameter $2.5 \mathrm{~mm}$ ) where fish were less than $125 \mathrm{~mm}$ in length. Flushing was not carried out on fish of less than $65 \mathrm{~mm}$ in length, diet instead being assessed from a small sub-sample collected for laboratory analysis.

Stomach contents were identified to the same taxonomic levels as the drift samples. The wet weight of each diet sample was recorded, from which a gut-fullness index was calculated in correspondence with fish weight (Turnpenny et al., 1987):

Gut-fullness Index $=$ Weight of stomach contents $(\mathrm{g})$ $\times 10000 /$ fish weight $(\mathrm{g})$

\section{DATA ANALYSIS}

Variations in key variables (e.g. the density and biomass of aquatic, terrestrial and all organisms; trout condition and gut-fullness; dietary contributions by important prey) 
between acid and circumneutral streams, and between riparian land-uses, were assessed by hierarchical two-way ANOVA using general linear modelling (GLM). Land-uses were nested within acid categories. The most likely sources of any significant effects were then identified by a posteriori multiple comparisons using Tukey-Kramer range tests. In all ANOVAS, data were transformed where necessary to homogenise variances, following diagnostic procedures recommended by Fry (1993). To avoid pseudoreplication (Hurlbert, 1984) in the ANOVAs, bulked or mean values were used from all the samples at each site, thus ensuring that the experiment identified individual rivers correctly as the replicated treatment units.

\section{Results}

\section{BENTHIC INVERTEBRATES}

Forty-six families of aquatic invertebrates occurred in the benthic samples, with 9-26 at any one site. Total abundances $\left(\mathrm{F}_{1,24}=11.06, P<0.003\right)$, taxon richness $\left(\mathrm{F}_{1,24}=12.87\right.$, $P<0.001)$ and biomass $\left(\mathrm{F}_{1,24}=17.98, P<0.001\right)$ were all significantly reduced at acidic in comparison with circumneutral sites, but in no case was there an additional significant effect of land-use (Fig. 1). At the order level, ephemeropterans, plecopterans and coleopterans were less numerous at acid than circum-neutral sites $\left(\mathrm{F}_{1,24}=6.39-\right.$ 20.87, all $P<0.02$ ), but again there were no land-use effects.

\section{MACROINVERTEBRATE DRIFT}

There were no circadian patterns in the drift of terrestrial invertebrates (day $v s$ night ANOVA, $\mathrm{F}_{1,28}=0.01, P=0.942$ ), but, in keeping with well-known patterns, significantly greater densities of aquatic invertebrates drifted at night than during the day (ANOVA, $\mathrm{F}_{1,28}=12.93, P<0.001$ ). All drift analyses were, therefore, repeated on samples from the whole circadian cycle, and those taken during the daylight hours (i.e. 08.00 to 20.00).

Fifty-one aquatic families occurred in the drift. Reflecting patterns in the benthos, taxon richness was lower at acid than circumneutral sites irrespective of land-use. Nine terrestrial orders occurred, with taxon richness unaffected by acidity, but significantly reduced in moorland by comparison with conifers or broadleaves (Tables 2, 3). Terrestrial drift was dominated by adult Diptera (see Table 2 v 4).

Over the full circadian cycle, the density and biomass of aquatic drift were significantly greater at circumneutral than acidic sites (Tables 2,3). Differences were clear in all landuse categories, while land-use itself had no significant effect. Neither terrestrial drift density nor biomass was affected in
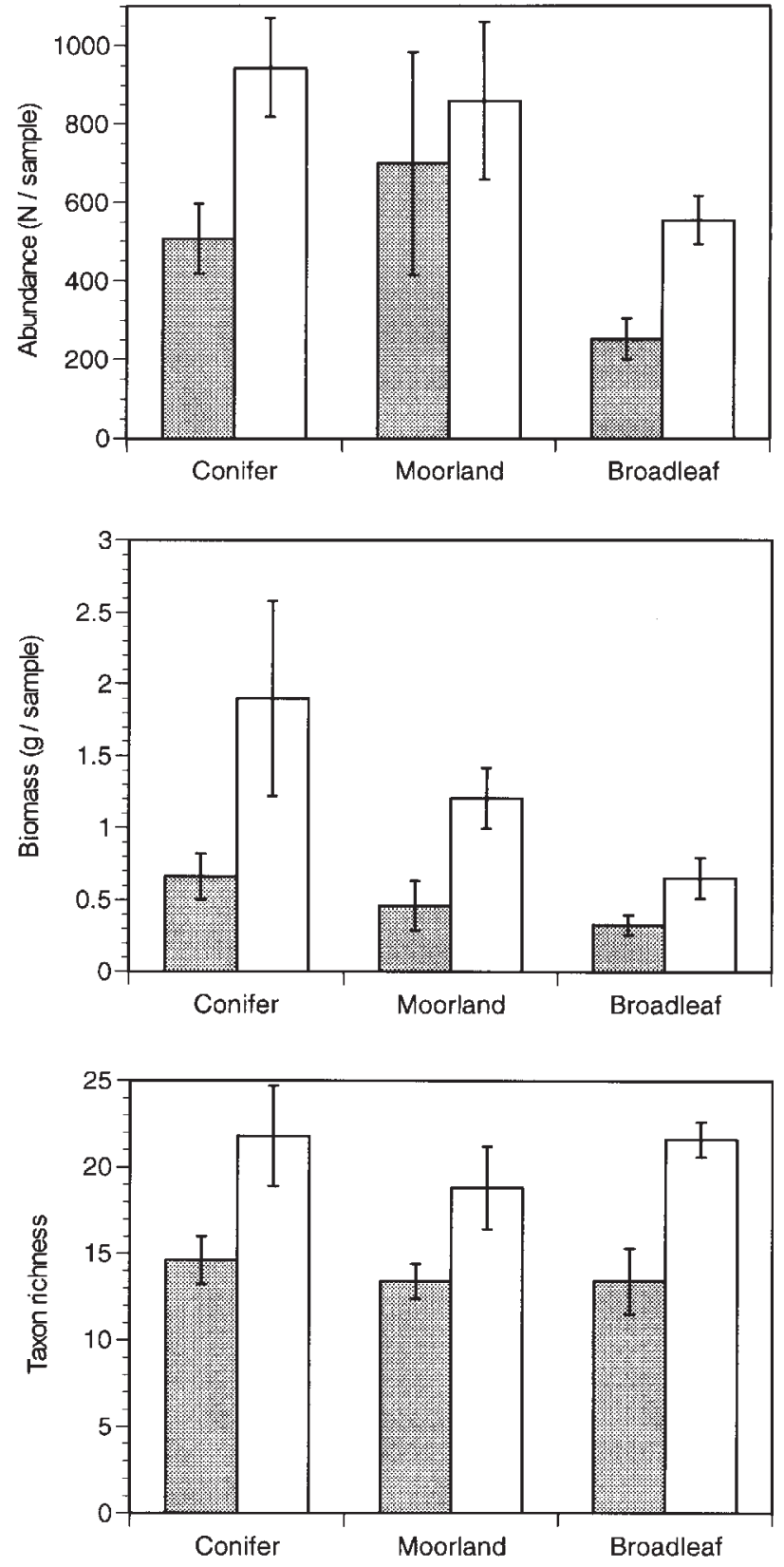

Fig. 1. Benthic invertebrates at 30 acid (shaded) and circumneutral sites in upland Wales in contrasting types of riparian land use. The values are means $( \pm S E)$ for each set of five sites, and statistical analyses are in the text.

absolute terms by acidity or land-use, but terrestrial invertebrates made a significantly greater proportionate contribution to total drift density at acid sites as aquatic contributions declined. Terrestrial drift also made a proportionately larger contribution to total drift biomass at circumneutral broadleaf sites than in acid moorlands (TukeyKramer, $P<0.01)$. Patterns in total drift biomass and density most strongly paralleled those in aquatic drift, and varied only with acidity. 
Table 2. Invertebrate drift in 30 acid and circumneutral streams in upland Wales in contrasting types of riparian land-use during JulySeptember. The values are geometric means (x or $\div$ by S.D.) for each set of five sites. See Table 3 for statistical analysis.

\begin{tabular}{|c|c|c|c|c|c|c|}
\hline \multirow[b]{2}{*}{ Drift measurement: } & \multicolumn{3}{|l|}{ ACID SITES } & \multicolumn{3}{|c|}{ Circumneutral sites } \\
\hline & Conifer & Broadleaf & Moorland & Conifer & Broadleaf & Moorland \\
\hline Aquatic families & $10.5(1.15)$ & $11.4(1.24)$ & $9.1(1.18)$ & $13.6(1.09)$ & $16.8(1.48)$ & $13.7(1.50)$ \\
\hline Terrestrial orders & $5.5(1.23)$ & $6.2(1.14)$ & $4.1(1.23)$ & $5.7(1.55)$ & $6.9(1.24)$ & $4.3(1.47)$ \\
\hline Aquatic density (nos $\mathrm{m}^{-3}$ ) & $1.9(2.09)$ & $1.3(2.59)$ & $2.2(2.18)$ & $4.4(3.66)$ & $3.1(1.92)$ & $12.0(3.48)$ \\
\hline Terrestrial density $\left(\right.$ nos $\left.\mathrm{m}^{-3}\right)$ & $2.3(2.60)$ & $3.2(1.75)$ & $2.1(2.53)$ & $1.8(1.67)$ & $3.2(2.00)$ & $3.5(2.44)$ \\
\hline Total density $\left(\operatorname{nos} \mathrm{m}^{-3}\right)$ & $4.6(2.10)$ & $4.7(1.89)$ & $4.8(2.03)$ & $7.7(2.28)$ & $6.9(1.57)$ & $16.8(2.99)$ \\
\hline Aquatic biomass $\left(\mathrm{mg} \mathrm{m}^{-3}\right)$ & $8.1(2.33)$ & $5.4(2.49)$ & $6.2(2.47)$ & $12.4(3.00)$ & $13.9(1.96)$ & $27.3(3.41)$ \\
\hline Terrestrial biomass $\left(\mathrm{mg} \mathrm{m}^{-3}\right)$ & $5.2(2.77)$ & $7.0(1.51)$ & $3.0(2.74)$ & $3.3(1.98)$ & $7.3(2.41)$ & $4.6(2.28)$ \\
\hline Total biomass $\left(\mathrm{mg} \mathrm{m}^{-3}\right)$ & $19.7(2.46)$ & $20.1(1.72)$ & $13.1(2.46)$ & $24.0(1.50)$ & $38.7(1.97)$ & $40.6(2.72)$ \\
\hline
\end{tabular}

Table 3. Results of two-way ANOVAs assessing effects of land use (DF 4,24), nested within effects of acidity (DF 1,24) on measures of invertebrate drift over $24 \mathrm{~h}$ at 30 sites in upland Wales. See Table 2 for the actual data.

\begin{tabular}{llllll}
\hline Effect & Acidity & \multicolumn{3}{c}{ Land Use } \\
Drift measurement & F-ratio & $P$ & F ratio & $P$ \\
\hline Aquatic families & 12.76 & $<0.01$ & 0.98 & $\mathrm{NS}$ \\
Terrestrial orders & 0.4 & $\mathrm{NS}$ & 2.87 & $<0.05$ \\
Aquatic drift density & 9.97 & $<0.01$ & 1.49 & $\mathrm{NS}$ \\
Terrestrial drift density & 0.07 & $\mathrm{NS}$ & 0.68 & $\mathrm{NS}$ \\
Total drift density & 6.54 & $<0.05$ & 0.99 & $\mathrm{NS}$ \\
Terrestrial \% (Density) & 6.82 & $<0.05$ & 2.78 & $<0.05$ \\
Aquatic drift biomass & 7.27 & $<0.05$ & 0.60 & $\mathrm{NS}$ \\
Terrestrial drift biomass & 0.19 & $\mathrm{NS}$ & 2.07 & $\mathrm{NS}$ \\
Total drift biomass & 5.49 & $<0.05$ & 0.61 & $\mathrm{NS}$ \\
Terrestrial \% (Biomass) & 4.29 & 0.05 & 4.27 & 0.05 \\
\hline
\end{tabular}

In addition to drift quantity, acidity influenced drift composition. There were significantly greater drift densities of both Ephemeroptera $\left(\mathrm{F}_{1,24}=10.82, P<0.01\right)$ and
Plecoptera $\left(\mathrm{F}_{1,24}=10.3, P<0.01\right)$ at circumneutral compared with acidic sites, although differences for Plecoptera were modest in absolute terms (Table 4). Other groups were unaffected, and no differences of this type occurred between land-uses (all $\mathrm{F}_{4,24}=0.6-1.1, \mathrm{NS}$ ).

All these patterns in drift were unchanged qualitatively when only daylight samples were considered.

\section{TROUT CONDITION}

There was no significant difference in trout length between streams of different $\mathrm{pH}\left(\mathrm{F}_{1,24}=0.16\right.$, NS $)$ or riparian vegetation $\left(\mathrm{F}_{4,24}=0.10, \mathrm{NS}\right)$, nor were there any variations in weight $\left(\mathrm{F}_{1,24}=1.01\right.$, NS, for acidity; $\mathrm{F}_{2,24}=1.57$, NS, for land-use). Thus, all the following comparisons, based on 393 trout in the case of gut-fullness and diet, were independent of fish size variation between sites.

Although gut-fullness appeared low at acid sites in moorland (Fig. 2), values were variable so that there were no significant effects of either acidity $\left(\mathrm{F}_{1,24}=2.0 \mathrm{NS}\right)$ or land-use $\left(\mathrm{F}_{4,24}=0.97, \mathrm{NS}\right)$. By contrast, condition varied strongly, but not due to effects of acidity $\left(\mathrm{F}_{1,24}=0.00, \mathrm{NS}\right)$;

Table 4. Major components of drift in 30 acid and circum-neutral streams in upland Wales in contrasting types of riparian land-use during July-September 1996. The values are geometric mean densities ( $\mathrm{x}$ or $\div$ by S.D; $\mathrm{n} \mathrm{m}^{-3}$ ) for each set of five sites. See text for statistical analysis.

\begin{tabular}{|c|c|c|c|c|c|c|}
\hline \multirow[b]{2}{*}{ Drift measurement: } & \multicolumn{3}{|l|}{ ACID SITES } & \multicolumn{3}{|c|}{ Circumneutral sites } \\
\hline & Conifer & Broadleaf & Moorland & Conifer & Broadleaf & Moorland \\
\hline Nymphal Ephemeroptera & $1.4(1.38)$ & $1.3(1.66)$ & $1.5(1.99)$ & $3.4(3.66)$ & $2.7(2.23)$ & $5.8(2.33)$ \\
\hline Nymphal Plecoptera & $1.1(1.13)$ & $1.1(1.06)$ & $1.3(1.32)$ & $1.6(1.31)$ & $1.3(1.23)$ & $1.5(1.17)$ \\
\hline Larval Trichoptera & $0.2(1.29)$ & $0.3(1.13)$ & $0.3(1.34)$ & $0.3(1.20)$ & $0.3(1.08)$ & $0.5(1.11)$ \\
\hline Larval Diptera & $1.0(1.43)$ & $0.5(1.29)$ & $0.5(1.47)$ & $0.6(1.17)$ & $0.3(1.19)$ & $2.8(3.59)$ \\
\hline Adult Diptera & $2.5(1.7)$ & $3.5(1.55)$ & $2.7(1.95)$ & $1.9(1.33)$ & $3.3(1.9)$ & $3.9(1.73)$ \\
\hline
\end{tabular}



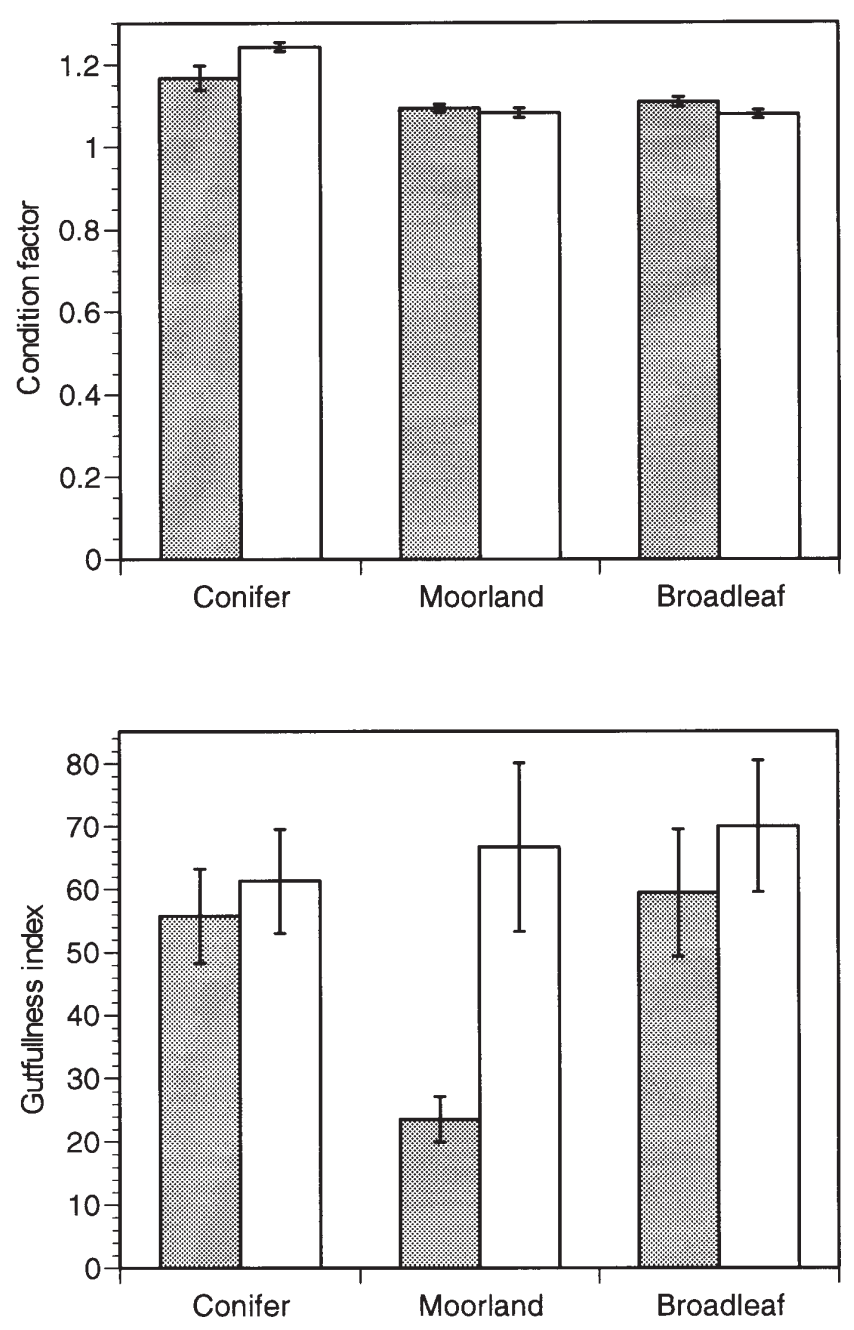

Fig. 2. The condition (top) and gut fullness (below) of brown trout at 30 acid (shaded) and circumneutral sites in upland Wales in contrasting types of riparian land use. The values are means $( \pm S E)$ for each set of five sites, and statistical analyses are in the text.

instead, values were significantly higher in both acid and circumneutral conifer streams $\left(\mathrm{F}_{4,24}=4.18, P<0.01\right.$ and Tukey-Kramer Range tests, $P<0.05$; Fig. 2). This result was not explained by lower fish density at conifer sites, since condition was unrelated to density across the whole suite of 57 sites in the larger investigation of which this formed part $(r=0.05, \mathrm{NS})$.

\section{TROUT DIET}

Fifty-seven aquatic invertebrate families and twelve terrestrial orders were identified in trout diet. Dietary composition was significantly affected by both land-use and acidity, with some results consistent with those in the drift. For example, the proportion of terrestrial invertebrates eaten varied with land-use due to significantly increased contributions at broadleaf sites (Table 5, Fig. 3 and Tukey-
Table 5. Results of two-way ANOVAs assessing effects of land use (DF 4,24), nested within effects of acidity (DF 1,24) on invertebrate contributions to trout diet at 30 sites in upland Wales. See Fig. 3 for the actual data.

\begin{tabular}{llllll}
\hline Effect & Acidity & \multicolumn{4}{c}{ Land use } \\
Prey type: & F-ratio & $P$ & F-ratio & $P$ \\
\hline Nymphal Ephemeroptera & 51.54 & $<0.001$ & 17.23 & $<0.001$ \\
Nymphal Plecoptera & 19.13 & $<0.001$ & 3.87 & $<0.01$ \\
Adult Coleoptera & 3.07 & NS & 7.46 & $<0.01$ \\
Larval Trichoptera & 2.57 & NS & 3.91 & $<0.01$ \\
Larval Diptera & 10.27 & $<0.01$ & 6.1 & $<0.01$ \\
Adult Diptera & 2.53 & NS & 19.02 & $<0.001$ \\
Terrestrial prey & 1.22 & NS & 16.87 & $<0.001$ \\
$(\%$ of total items) & & & & \\
\hline
\end{tabular}

Kramer range tests, $P<0.05$ ); across all the sites the proportion of terrestrial prey eaten increased with the proportion of terrestrial invertebrates in the drift (Fig. 4). Also consistent with drift data, significantly more plecopterans and ephemeropterans were eaten at circumneutral than at acid sites (Fig. 3; Table 5). Here, however, effects of land-use due to dietary contributions by Plecoptera in circumneutral conifer sites were greater than at all other sites except circumneutral broadleaf sites (TukeyKramer Range tests, $P<0.05)$. Ephemeropteran dietary contributions were affected by land-use within and between acid categories, with several pairwise differences being significant (Table 6).

Other significant dietary effects were specific to certain site-group and varied mostly with land-use. These included weak patterns among larval trichopterans due to differences between acid conifer and circumneutral moorland; effects of land-use and acidity on larval dipterans due to increased contributions, particularly from chironomids, in acid conifers; effects of land-use on coleopterans due to increased contributions in acid broadleaves; and effects of land-use and acidity on adult Diptera reflecting increased contributions in both broadleaf and acid moorland sites (Fig. 3; Table 6).

\section{Discussion}

Initial predictions about variations in drift and benthos with acidity were verified: the numbers, biomass and taxon richness of drifting aquatic invertebrates were significantly reduced at acid sites reflecting well-known acidification effects on the composition of aquatic fauna. By contrast, terrestrial invertebrates were unaffected except in their 

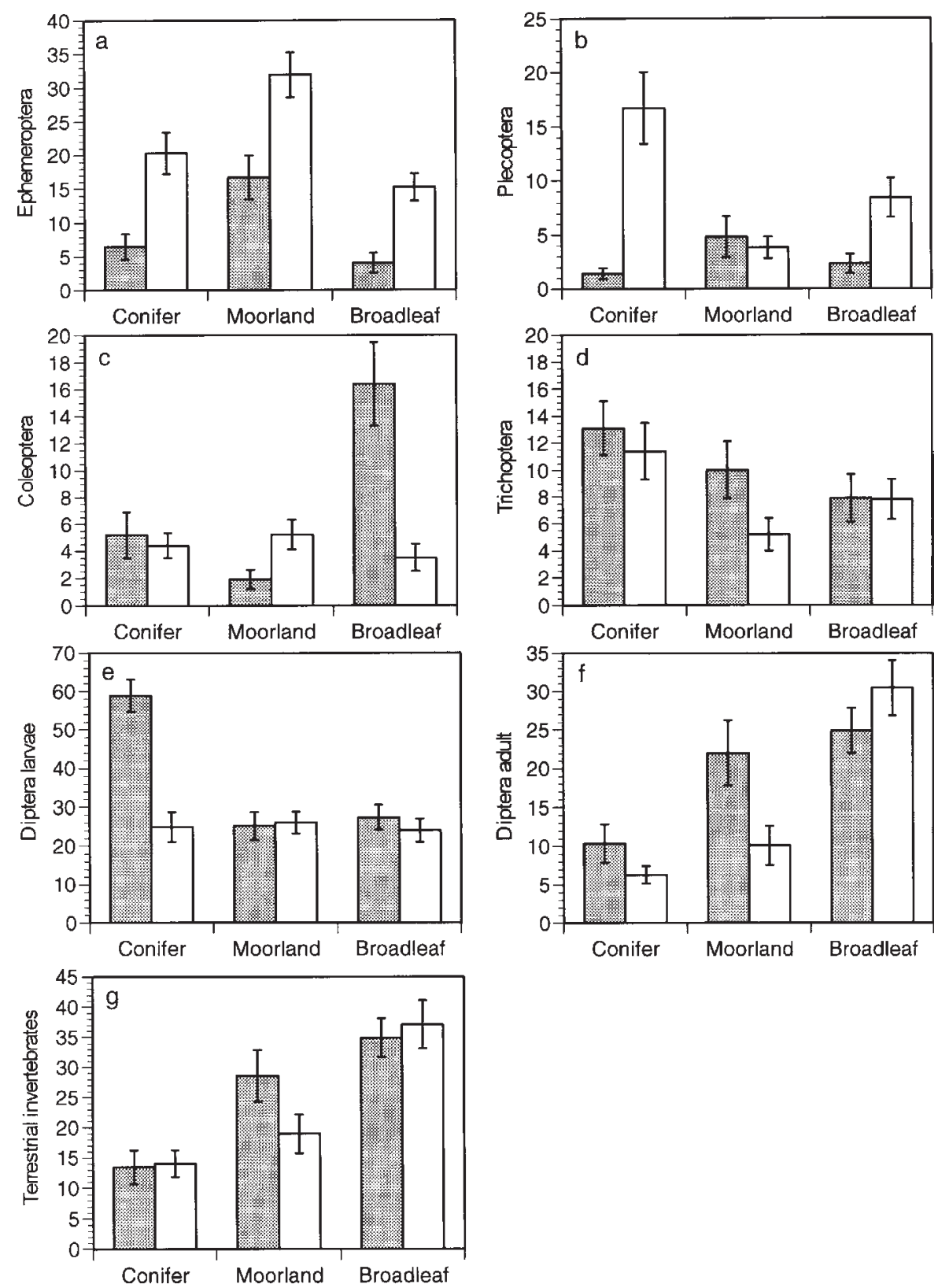

Fig. 3. Percentage contributions (by numbers of items) by different prey to the diets of brown trout at 30 acid (shaded) and circumneutral sites in upland Wales in contrasting types of riparian land use. The values are means ( \pm SE) for each set of five sites, and statistical analyses are in Table 5 .

proportionate contribution to total drift. Predicted effects of riparian land-use on terrestrial drift were upheld partly, with proportionate contributions to total biomass greatest in circumneutral broadleaf streams; however, no significant drift reduction occurred under conifers. Predictions concerning trout were also falsified: although some aspects of diet quality reflected drift, acidity and land-use, gutfullness was nowhere significantly reduced. Most unexpectedly of all, trout at conifer sites were apparently in 'better' condition than trout elsewhere. Two elements of caution required in interpreting these results are, firstly, that the study focused on the summer period, so that trophic effects of acidity and land use on trout at other times cannot be excluded; secondly, the investigation required the presence of trout at all the sites, so that site selection was biased towards rivers capable of supporting them.

\section{EFFECTS ON DRIFT AND BENTHOS}

Most of the drifting aquatic invertebrates recorded at the sites were either stoneflies or mayflies, and much of the reductions in aquatic drift at acidic sites reflected the scarcity 


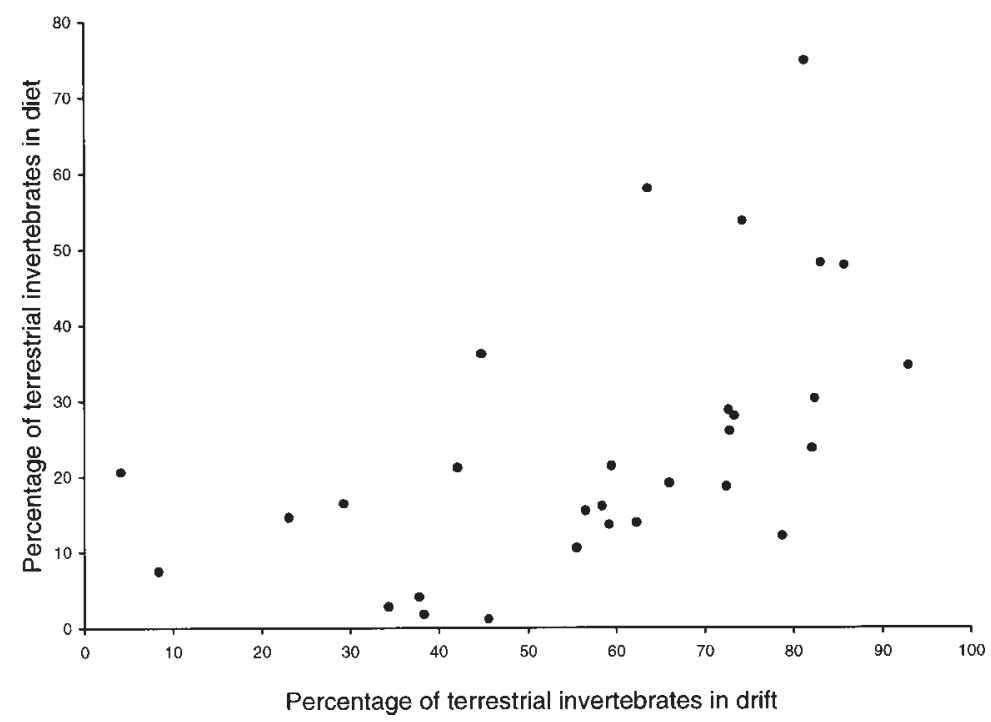

Fig. 4. Percentage contribution (by number of items) to the diet of brown trout by terrestrial inverts at 30 sites in upland Wales in relation to their percentage occurrence in invertebrate drift (Pearson's $\mathrm{r}=0.547, \mathrm{P}<0.05$ ).

Table 6. Pairwise differences, shown by a posteriori comparisons in the contributions made by different prey types to the diets of brown trout at 30 sites in upland Wales (see Figure 3 ). Identical letters indicate differences significant at $\mathrm{P}<0.05$.

\begin{tabular}{lcccccc}
\hline & \multicolumn{3}{c}{ ACID sites } & & \multicolumn{3}{c}{ Circum-Neutral sites } \\
Prey Type: & Conifer & Broadleaf & Moorland & Conifer & Broadleaf & Moorland \\
\hline Ephemeroptera & $\mathrm{A}$ & $\mathrm{BCDE}$ & $\mathrm{BF}$ & $\mathrm{CG}$ & $\mathrm{DH}$ & AEFGH \\
Plecoptera & $\mathrm{A}$ & $\mathrm{B}$ & $\mathrm{C}$ & $\mathrm{ABCD}$ & & $\mathrm{D}$ \\
Coleoptera & $\mathrm{A}$ & $\mathrm{ABCDE}$ & $\mathrm{B}$ & $\mathrm{C}$ & $\mathrm{D}$ & $\mathrm{E}$ \\
Larval Diptera & $\mathrm{ABCDE}$ & $\mathrm{A}$ & $\mathrm{B}$ & $\mathrm{C}$ & $\mathrm{D}$ & $\mathrm{E}$ \\
Adult Diptera & $\mathrm{AB}$ & $\mathrm{ACD}$ & $\mathrm{E}$ & $\mathrm{CEF}$ & $\mathrm{BFG}$ & $\mathrm{DG}$ \\
Terrestrial prey & $\mathrm{AB}$ & $\mathrm{ACD}$ & & $\mathrm{CE}$ & $\mathrm{BEF}$ & $\mathrm{DF}$ \\
\hline
\end{tabular}

of the latter. Reductions in plecopteran numbers at low $\mathrm{pH}$ were modest but significant, and might be considered atypical, since this group is considered acid tolerant. However, there are acid-sensitive species among the Chloroperlidae, Leuctridae, Perlodidae and Perlidae, and they were responsible for most of the patterns in this investigation (e.g. Wade et al., 1989; Rutt et al., 1990). In addition, larval plecopterans are typically scarce at acid sites during the period of this experiment, reflecting life-cycles with spring and summer flight periods (Weatherley et al., 1989).

The absence of effects of land use on benthos or aquatic drift illustrates the dominant effect of acid-base status on macroinvertebrate communities in upland British rivers. Grazing ephemeropterans, which can proliferate in the absence of shading from conifers or broadleaves (e.g.
Hawkins et al., 1983), will be excluded irrespective of riparian land use at low $\mathrm{pH}$ by their acid sensitivity (Rutt $e t$ al., 1990). Until recovery from acidification progresses further, therefore, acidification will impose limits on the effects of riparian vegetation management on some invertebrate groups in affected streams. There are, nevertheless, management options for increasing aquatic invertebrate productivity even at acid sites: increased density among acid-tolerant leaf-shredding trichopterans or plecopterans might result where riparian broadleaves increase allochthonous litter. Small-scale manipulations at low pH confirm this effect (Dobson et al., 1995), but evidence that it scales-up to whole streams is still patchy (Ormerod et al., 1993; Pretty and Dobson, 2004).

Managing riparian zones to increase energy subsidies to stream systems from of terrestrial invertebtrates offers a 
further option for increasing aquatic secondary production. Terrestrial drift can reflect land use, since both the numbers and biomass of insects falling into rivers varies between riparian canopies (Mason and MacDonald, 1982; Ormerod and Tyler, 1991). This effect was confirmed here by increased numbers of terrestrial invertebrates under broadleaf trees, where they contributed more to drift biomass and trout diet. The lack of any significant opposite effect at conifer sites was surprising in view of the marked reductions in terrestrial invertebrate numbers and biomass falling into rivers under conifer canopies (Ormerod and Tyler, 1991). Results of this latter type have been attributed to the low density and diversity of insects on conifers, particularly exotic species (Kennedy and Southwood, 1984). There are also contrasting seasonal patterns, with invertebrate inputs from broadleaf trees remaining constant through the summer, while those from conifers increase in July and August (Ormerod and Tyler, 1991); the timing of the experiment is therefore important, since it coincided with the period when invertebrate inputs from conifers would be greatest. Nevertheless, the data, at least from circumneutral sites, show that prey inputs to streams are not reduced inevitably under conifers at the times when trout feed on terrestrial prey. However, strips of riparian broadleaf trees in plantation forests appear to provide even greater prey inputs, with benefits to a range of other organisms in addition to fishes (Ormerod and Tyler, 1991). This energy subsidy might well be disproportionately important for otherwise impoverished acid streams, and support the suggestion elsewhere in this volume that native tree species should form an important riparian element in forest planting (Broadmeadow and Nisbet, 2004).

\section{EFFECTS ON TROUT}

Variations in trout diet between site types during this study illustrate the well-known opportunistic foraging shown by this mobile and opportunistic predator (Valente and Helande, 1990). Not only can it switch between prey types, but also between micro-habitats in a way that complicates attempts to quantify true prey availability. For example, trout at acid conifer sites fed predominantly on chironomids from the benthos, while at other sites terrestrial prey were taken from the drift in proportion to their occurrence. Flexibility of this type would explain how trout maintained gut-fullness, even though there were variations between sites in the abundances of drifting or benthic prey. Perhaps reduced trout density at acid sites in Wales prevents intra-specific competition, prey depletion and, hence, reductions in individual food intake (Turnpenny et al., 1987; Milner and Varallo, 1990). Overall, the present data support Turnpenny et al. (1987), who considered it more likely that direct toxicity restricted trout from acid waters rather than food scarcity, a conclusion well supported by ecotoxicological data (e.g. Weatherley et al., 1990 for Wales). Nevertheless, increasing foraging opportunities and food abundance for stream salmonids might become important as streams recover from acidification, and the data show that riparian broadleaf trees will be most effective in this respect.

Enhanced trout condition at conifer sites was the most unexpected result of all. This occurred in both $\mathrm{pH}$ groups, so appeared independent of major-ion chemistry; it appeared in the absence of consistent trends in drift or benthic abundances and so was independent of putative measures of food abundance; also it was not associated with changing fish length or density. In addition, increased condition at conifer sites should be seen in the light of a range of supposed ecological effects on streams by plantations, including alterations in hydrology, temperature regime, erosion, sediment yields and habitat structure that might be considered harmful to trout (Ormerod et al., 1987; 1993; Rutt et al., 1989; Weatherley and Ormerod, 1990; Weatherley et al., 1991). In the absence of any firm explanation, recent climatic patterns offer one possibility. In Wales, diel and seasonal variations in temperature are reduced at conifer sites by comparison with adjacent moorland, due probably to insulation and shading (Gray and Edington, 1969; Weatherley and Ormerod, 1990). Mean summer temperatures are lower, and at the Llyn Brianne experimental catchments, Weatherley and Ormerod (1990) used models to show how trout in forest streams should weigh $30 \%$ less after the second year of growth than trout in adjacent moorlands. However, if average temperatures were only $1-3{ }^{\circ} \mathrm{C}$ greater than in these simulations, this effect would be negated because higher minima and lower maxima in conifers would keep temperatures in the optimum growth range for longer. The occurence of warmer years preceding the collection of these data might well have led to faster trout growth. Similar advances in trout growth and emergence have occurred elsewhere in non-forest streams in upland Britain during the recent positive (i.e. warmer) phase of the North Atlantic Oscillation (Elliott et al., 2000), a phenomenon also tracked by Welsh stream ecosystems (Bradley and Ormerod, 2001).

\section{Acknowledgements}

Thanks are due to Phil Brewin and Steve Wilkinson for help with fieldwork. The work was carried out in 1995 and funded by the former Welsh Office, Environment Agency, Countryside Council for Wales, Forestry Commission and a NERC studentship to MEJ. CEH Bangor made available 
chemical data collected during this programme.

\section{References}

Allan, J.D. and Russek, E., 1985. The quantification of stream drift. Can. J. Fisheries Aquat. Sci., 42, 210-215.

Allan, J.D., Wipfli, M.S., Caouette, J.P., Prussian, A. and Rodgers, J., 2003. Influence of streamside vegetation on inputs of terrestrial invertebrates to salmonid food webs. Can. J. Fisheries Aquat. Sci., 60, 309-320.

Bachman, R.A., 1984. Foraging behaviour of free-ranging wild and hatchery trout in a stream. Trans. Amer. Fisheries Soc., $113,1-32$.

Bohlin, T., Hamrin, S., Heggberget, T.G., Rasmussen, G. and Saltveit, S.J., 1989. Electrofishing - Theory and practice with special emphasis on salmonids. Hydrobiologia, 173, 9-43.

Bradley, D.C. and Ormerod, S.J., 2001. Community persistence among stream invertebates tracks the North Atlantic Oscillation. J. Anim. Ecol., 70, 987-996.

Bridcut, E.E., 2000. A study of terrestrial and aerial macroinvertebrates on river banks and their contribution to drifting fauna and salmonid diets in a Scottish catchment. Hydrobiologia, 427, 83-100.

Broadmeadow, S. and Nisbet, T.R., 2004. The effects of riparian forest management on the freshwater environment - a lliterature review of best practice management. Hydrol. Earth Syst. Sci., 8, 286-305.

Collen, P., Keay, E.J. and Morrison, B.R.S., 2004. Processing of pine (Pinus sylvestris) and birch (Betula pubescens) leaf material in a small river system in the northern region of the Cairngorms, Scotland. Hydrol. Earth Syst. Sci., 8, 567-577.

Dobson, M., Hildrew, A.G., Orton, S. and Ormerod, S.J., 1995. Increasing litter retention in moorland streams: ecological and management aspects of a field experiment. Freshwater Biol., 33, 325-337.

Elliott, J.M., 1970. Diel changes in invertebrate drift and the food of trout Salmo trutta L. J. Fish Biol., 2, 161-165.

Elliott, J.M., Hurley, M.A. and Maberly, S.C., 2000. The emergence period of sea trout fry in a Lake District stream correlates with the North Atlantic Oscillation. J. Fish Biol., 56, 208-210.

England, L.E. and Rosemond, A.D., 2004. Small reductions in forest cover weaken terrestrial-aquatic linkages in headwater streams. Freshwater Biol., 49, 721-734.

Foster, J.R., 1977. Pulsed gastric lavage: An efficient method of removing the stomach contents of live fish. Prog.Fish Cult., 39, 166-169.

Fry, J.C., 1993. Biological Data Analysis. Oxford University Press, Oxford, UK.

Gray, J.R.A. and Edington, J.M., 1969. Effect of woodland clearance on stream temperature. J. Fisheries Res.Board Can., 26, 399-403.

Harriman, R. and Morrison, B.R.S., 1982. Ecology of streams draining forested and non-forested catchments in an area of central Scotland subject to acid deposition. Hydrobiologia, 88, 251-263.

Hawkins, C.P., Murphy, M.L., Anderson, N.H. and Wilzbach, M.A., 1983. Density of fish and salamanders in relation to riparian canopy and physical habitat in streams of the NorthWestern United States. Can. J. Fisheries Aquat.Sci., 40, 11731185.

Hurlbert, S.H., 1984. Pseudoreplication and the design of ecological experiments. Ecol. Monogr. 54, 187-211.
Kawaguchi, Y., Taniguchi, Y, and Nakano, S., 2003. Terrestrial invertebrate inputs determine the local abundance of stream fishes in a forested stream. Ecology, 84, 701-708.

Kelly-Quin, M., 1991. The diel feeding patterns of brown trutta (Salmo trutta L.) in acid streams during the summer and autumn months. In: Irish rivers: Biology and Management M. Steer (Ed.), Royal Irish Academy, Dublin, Ireland. 47-57.

Kelly-Quin, M. and Bracken, J.J., 1990. A seasonal analysis of the diet and feeding of brown trout Salmo trutta L. in a small nursery stream. Aquacult. Fisheries Manage., 21, 107-124.

Kennedy, C.E.J. and Southwood, T.R.E., 1984. The number of species of insects associated with British trees: a re-analysis. $J$. Anim. Ecol., 53, 455-478.

Light, R.W., Adler, P.H. and Arnold, D.E., 1983. Evaluation of Gastric lavage for stomach analyses. N. Amer. J. Fisheries Manage., 3, 81-85.

Mason, C.F. and MacDonald, S.M., 1982. The input of terrestrial invertebrates from tree canopies to a stream. Freshwater Biol., 12, 305-311.

Milner, N.J. and Varallo, P.V., 1990. Effects of acidification on fish and fisheries in Wales. In: Acid Waters in Wales R.W. Edwards, A.S. Gee, and J.H. Stoner (Eds.), Kluwer, The Hague. the Netherlands.

Morris, R., Taylor, E.W., Brown, D.J.A. and Brown, J.A., 1989. Acid toxicity and aquatic animals. Cambridge University Press, Cambridge, UK.

Nakano, S. and Murakami, M., 2001. Reciprocal subsidies: Dynamic interdependence between terrestrial and aquatic food webs. Proc. Nat. Acad. Sci. USA, 98, 166-170.

Nakao, S., Miyasaka, H. and Kuhara, N., 1999. Terrestrial-aquatic linkages:Riparian arthropod inputs alter trophic cascades in a stream food web. Ecology, 80, 2435-2441.

Ormerod, S.J., Donald, A.P. and Brown, S.J., 1989. The influence of plantation forestry on the $\mathrm{pH}$ and aluminium concentration of upland Welsh streams: a re-examination. Environ. Pollut., 62, 47-62

Ormerod, S.J., Mawle, G.W. and Edwards, R.W., 1987. The influence of forestry on aquatic fauna. In: Environmental aspects of forestry production in Wales, J.E. Good (Ed.), Institute for Terrestrial Ecology, Bangor, UK. 37-49.

Ormerod, S.J., Rundle S.D., Lloyd, E.C. and Douglas, A.A., 1993. the influence of riparian management on the habitat structure and macroinvertebrate communities of upland streams draining plantation forests. J. Appl.Ecol., 30, 13-24.

Pretty, J.L. and Dobson, M., 2004. The response of macroinvertebrates to artificially enhanced detritus levels in plantation streams. Hydrol. Earth Syst. Sci., 8, 550-559.

Rutt, G.P., Weatherley, N.S. and Ormerod, S.J., 1989. Micro-habitat availability in Welsh moorland and forest streams as a determinant of macroinvertebrate distribution. Freshwater Biol., 22, 247-262.

Rutt, G.P., Weatherley, N.S. and Ormerod, S.J., 1990. Relationships between the physicochemistry and macroinvertebrates of upland British streams: the development of modelling and indicator systems for predicting fauna and detecting acidity. Freshwater Biol., 24, 463-480.

Sabo, J.L. and Power, M.E., 2002. River-watershed exchange: Effects of riverine subsidies on riparian lizards and their terrestrial prey. Ecology, 83, 1860-1869.

Sedell, J.R., Triska, F.J. and Triska, N.S., 1975. The processing of conifer and hardwood leaves in two coniferous forest streams: 1. Weight loss and associated invertebrates. Verh. Internat. Verein. Limnolog., 19, 1617-1627. 
Turnpenny, A.W.H., Sadler, K., Aston, R.J., Milner, A.G.P and Lynam, S., 1987. The fish populations of some streams in Wales and Northern England in relation to acidity and associated factors. J. Fish Biol., 31, 415-434.

Valente, A. and Heland, M., 1990. Observations on the feeding behaviour of trout (Salmo trutta L.) populations in the river Estoraos, Portugal. Bull. Fr. Peche Piscic.. 318, 132-144.

Wade, K.R., Ormerod, S.J. and Gee, A.S., 1989. Classification and ordination to predict stream acidity in upland Wales. Hydrobiologia, 171, 59-78.

Weatherley, N.S. and Ormerod, S.J., 1990. Forests and the temperature of upland streams in Wales - a modelling exploration of the biological effects. Freshwater Biol., 24, 109-122.
Weatherley, N.S. and Ormerod, S.J. 1991. The importance of acid episodes in determining faunal distributions in Welsh streams. Freshwater Biol., 25, 71-84.

Weatherley, N.S., Rutt, G.P. and Ormerod, S.J., 1989. Densities of benthic macroinvertebrates in upland Welsh streams of different acidity and land-use. Arch. Hydrobiol., 115. 417-431.

Weatherley, N S., Rogers, A.P., Goenaga, X. and Ormerod, S.J., 1990. The survival of early life stages of brown trout (Salmo trutta L.) in relation to aluminium speciation in upland Welsh streams. Aquat. Toxicol., 17, 213-230.

Weatherley, N.S., Campbell-Lendrum, E.W. and Ormerod, S.J., 1991. The growth of brown trout (Salmo trutta) in mild winters and summer droughts in upland Wales: model validation and preliminary predictions. Freshwater Biol., 26, 121-131. 